\title{
Correlation Analysis of In-Situ and Ex-Situ Sea Surface Temperature Relationships in Makassar Strait, South Sulawesi
}

\author{
Nur Abrianti Islamiah Baharuddin ${ }^{1}$, Mukti Zainuddin², Najamuddin² \\ ${ }^{1}$ Master Program, Postgraduate School, Hasanuddin University, Makassar, Indonesia \\ ${ }^{2}$ Faculty of Marine Sciences and Fisheries, Hasanuddin University, Makassar, Indonesia \\ Correspondence Author Email: nurabriantiislamiah0510.fishery@gmail.com \\ DOI: 10.29322/IJSRP.11.07.2021.p11566 \\ http://dx.doi.org/10.29322/IJSRP.11.07.2021.p11566
}

\begin{abstract}
Sea surface temperatures can change at any time due to several things, namely seasons and climate change. Makassar Strait waters which are located on the equator get 4 seasonal influences. Sea surface temperature Is one of the main indicators that can affect photosynthesis, directly and indirectly, thus affecting the abundance of aquatic organisms. Sea surface temperature is one of the parameters that can predict fish resources, one of which is flyfish. Indian Scad Fish are stenohaline organisms, so a slight change in sea surface temperature can change the distribution of the fish. The purpose of this study was to determine the correlation of in-situ sea surface temperature (field) and ex-situ sea surface temperature (Aqua-MODIS) by using a research sample of the coordinate point of the Indian Scad Fish ground from July to October in the waters of the Makassar Strait, South Sulawesi. Before the correlation analysis stage, the data was processed in SeaDAS software, Microsoft Excel 2019, ArcGIS10.2. The next data processing carried out data normality using the Shapiro-Wilk and Anderson-darling methods. Furthermore, in-situ and ex-situ correlation analysis using Pearson correlation method. All analyzes use Rstudio4.0.5. The results of the study can be concluded that there is a close relationship between in-situ sea surface temperature data with satellite images (ex-situ) of sea surface temperature in the Makassar Strait waters of $80.65 \%$. Meanwhile, a bias of $19.35 \%$ could be influenced by the presence of clouds in the atmosphere and solar radiation
\end{abstract}

Keywords: Correlation, Sea Surface Temperature In-Situ and Ex-situ, Makassar Strait

\section{INTRODUCTION}

Sea surface temperature is influenced by weather conditions, including rainfall, evaporation, humidity, wind speed, and solar

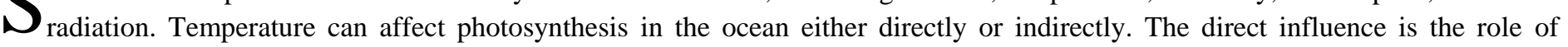
temperature in controlling enzymatic chemical reactions in the photosynthesis process. High temperatures can increase the maximum rate of photosynthesis, while the indirect effect is in changing the hydrological structure of the water column which can affect the distribution of phytoplankton [1].

Natural phenomena that can affect sea surface temperatures are seasons. Indonesia, which is located on the equator, gets 4 seasonal influences, namely the west season, the transitional season I, the east season, and transitional season II. In addition, sea surface temperature can be affected by climate change. Temperature is one of the physical properties of seawater that can affect the metabolism and growth of aquatic organisms. According to [2], sea surface temperature can be used as a parameter to predict the presence of organisms in water, especially fish. Based on temperature variations, the high and low-temperature variations are an important factor in determining the migration of a type of fish [3]. One type of fish catch that is widely caught is Indian Scad Fish (Decapterus, spp), mainly in the waters of the Makassar Strait. However, the total production of Indian Scad Fish catches every season and certain year fluctuates. This could be due to the increase in sea surface temperature as a result of global warming from year to year (climate change). Therefore, one effective and efficient way is to use remote sensing and Geographic Information Systems (GIS) to identify and manage Indian Scad Fish resources.

Various studies were carried out to determine the appropriate range of sea surface temperatures for flying fish [4] [5] [6]. This study aims to determine the correlation of field data (in-situ) with satellite image data (ex-situ) based on the location of Indian Scad Fish in the eastern season (July-August) and the transitional season II (September-October) in the Makassar Strait, South Sulawesi. 


\section{A. Study Area}

\section{MATERials AND Methods}

This research was carried out in waters where there are small pelagic fishing activities in the Makassar Strait $\left(118-120^{\circ} \mathrm{E}\right.$ and $3.62-5.38^{\circ} \mathrm{S}$ ). Based on the observations, two locations were determined that could support this research, first in Barru Regency with a fishing base in Siddo Village, and the second location in Pangkajene Kepulauan Regency with a fishing base on Sanane Island. In the two research sites, there is the fishing activity for Indian Scad Fish at night using purse seine boat catching units.

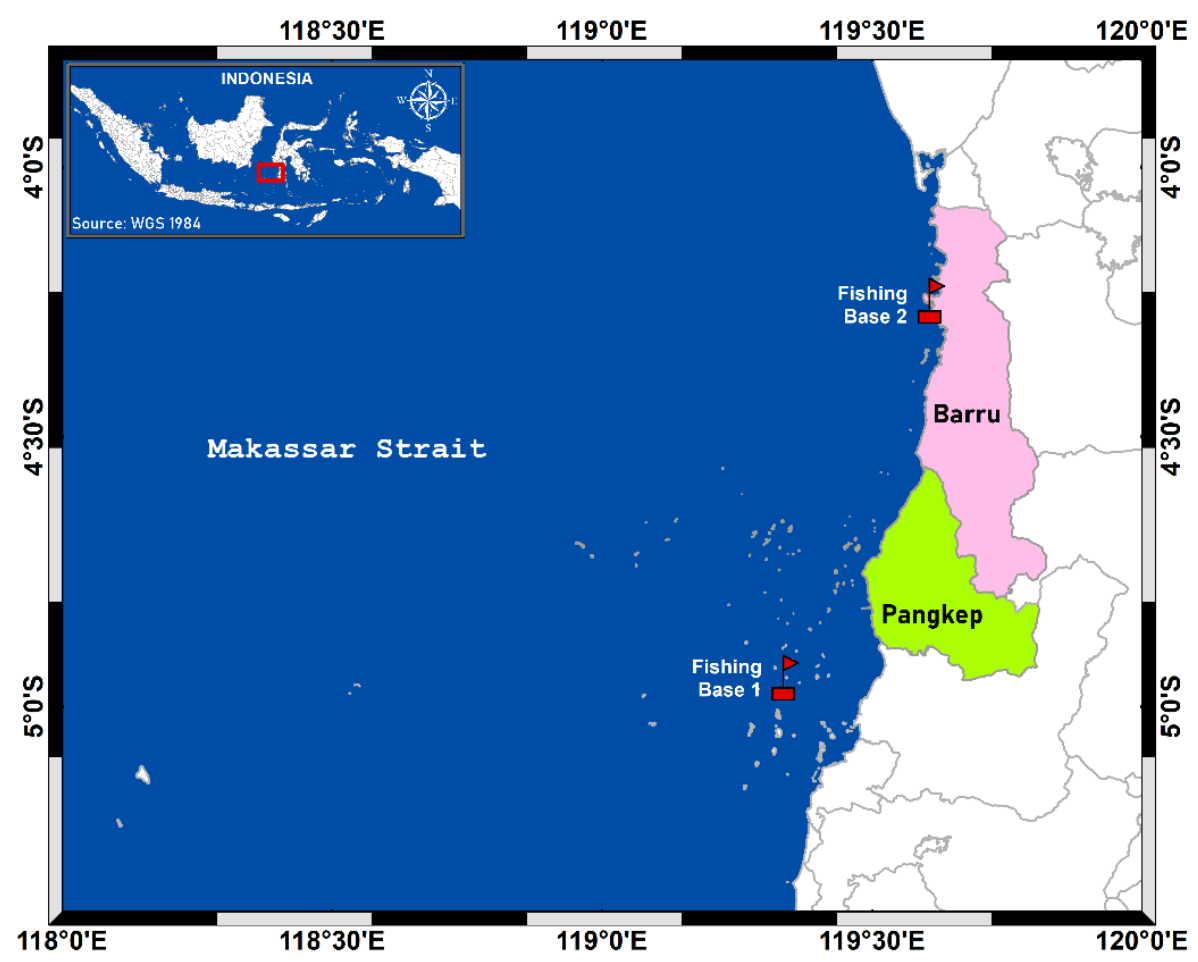

Figure 1: Research location

\section{B. In-situ data}

\section{Fishing Ground Coordinate Point}

The captain of the ship determines the fishing ground based on experience while at sea. When the captain has given a signal to the crew (ABK) to lower the net, then at that time the Global Positioning System (GPS) tool is used to find out the coordinates of the fishing ground. Coordinate point data collected is 50 fishing ground coordinate points.

\section{Sea Surface Temperature}

In-situ data was obtained by following the fishing operation of purse seine vessels at night from June to October 2020, the main purpose of which was to catch small pelagic fish. Seawater samples were determined based on the fishing ground. When the captain of the ship has determined the fishing location, the seawater sample is immediately taken using a bucket and placed on the ship's deck to make it easier to measure sea surface temperature using a digital thermometer accurately and record data per fishing ground.

The two data (sea surface temperature and fishing ground coordinates) are inputted in Microsoft Excel $2019 * \operatorname{csv}$ format and then used to determine the sea surface temperature in satellite imagery at each fishing ground coordinate point.

\section{Ex-situ data}

\section{Satellite Remote Sensing}

Ex-situ data in the form of sea surface temperature was obtained through the Aqua-Moderate Resolution Imaging Spectroradiometer (Aqua-MODIS) satellite data recording level 3 at $4 \mathrm{~km}$ resolution monthly downloaded from NASA on the website http://oceancolor.gsfc.nasa.gov. The boundaries of the research area are $118-120{ }^{\circ} \mathrm{E}$ and $3.62-5.38{ }^{\circ} \mathrm{S}$. The data that has been downloaded from Ocean-color and stored in *.nc format, is then reprocessed in the SeaWiFS Data Analysis System (SeaDAS) software 
to obtain sea surface temperature values and limit water areas. The data output from SeaDAS is in Text document (.txt) format and then the sea surface temperature data is stored in Microsoft Excel 2019 with *csv format.

The next process is data processing in ArcGIS10.2. The satellite image sea surface temperature data is interpolated to determine the distribution of sea surface temperature, then the fishing ground coordinates are extracted to determine the sea surface temperature of the satellite image.

\section{Data Analysis}

\section{Data Normality Test}

Shapiro-Wilk is one of the normality tests recommended by many experts if the number of samples is small, that is, less than or equal to 50 samples [7]. This test is very sensitive to detect any abnormal data distribution. The level of significance used is 5\% (0.05). The data distribution hypothesis is:

$$
\begin{aligned}
& H_{0}: \text { accepted, if p-value }>0.05 \text { (normal distribution) } \\
& H_{1} \text { : accepted, if p-value }<0.05 \text { (ubnormal distribution) }
\end{aligned}
$$

The Shapiro-Wilk test equation, as follows:

$$
G=b_{n}+c_{n-} \ln \left(\frac{T_{3}-d_{n}}{1-T_{3}}\right)
$$

where:

$$
\begin{aligned}
T_{3} & =\frac{1}{D}\left[\sum_{i=1}^{n} a_{i}\left(x_{n-i-1}-x_{i}\right)\right]^{2} \\
D & =\sum_{i=1}^{n}\left(x_{i}-\bar{x}\right)^{2}
\end{aligned}
$$

informastion:

$\mathrm{G}$

: identical to $\mathrm{Z}$ value of normal distribution;

$b_{n}, c_{n}, d_{n} \quad:$ Shapiro-Wilk statistical conversion with normal distribution approach;

$a_{i} \quad$ : Shapiro-Wilk coefficient;

$x_{i} \quad: i$-th data; and

$D_{i} \quad:$ the statistical value of the Shapiro-Wilk test.

Calculation of data normality test analysis using the Shapiro-Wilk method using Rstudio software with the following syntax:

$$
\text { shapiro.test(sst\$SST_L) }
$$

If the data normality test does not meet the requirements, then the next step is to carry out the Anderson-Darling normality test. The Anderson-Darling method is used to test whether the data sample comes from a population with a certain distribution. AndersonDarling is a modification of the Kolmogorv-Smirnov (KS) test. The critical values in the KS test do not depend on the particular distribution being tested while the Anderson-Darling test utilizes a certain distribution in calculating the critical value. This has the advantage of allowing more sensitive tests, but the disadvantage is that critical values must be calculated for each distribution [8]. Pvalue is the probability that the tested sample lies in the normal distribution of a population. If the p-value is less than 0.05 then the initial hypothesis is rejected $\left(H_{0}\right)$, then the Anderson-Darling test can be obtained using the following formula:

$$
A^{2}=-N-S
$$

where:

$$
\begin{aligned}
& S=\sum_{i=1}^{n}[2 i-1]\left[\log \left(F\left(Z_{i}\right)\right)+\log \left(1-F\left(Z_{n+1-i}\right)\right)\right] \\
& Z_{i}=\frac{x_{i}-\bar{x}}{S}
\end{aligned}
$$




\section{Information:}

A : The test statistic for the method of Anderson-Darling;

$n \quad$ : sample size;

$x_{i} \quad:$ the $i$-th data that has been sorted;

$Z_{i} \quad$ : standardized $x_{i}$ data;

$\bar{x} \quad$ : mean data;

$S \quad$ : standard deviation of data; and

$F\left(Z_{i}\right) \quad$ : the value of the standard normal cumulative distribution function in $Z_{i}$.

\section{Pearson Correlation Test}

The Pearson Linear correlation coefficient is a value that can measure how close a linear relationship occurs between two variables. The assumption used for the correlation test is that the paired data sample is quantitative data and the data pairs must be normally distributed. The value of the Pearson correlation coefficient ranges from -1 to +1 . The Pearson correlation coefficient value which is getting closer to +1 or -1 means that there is a strong linear relationship between the two variables. If it is close to 0 it indicates that there is a weak linear relationship between the two variables. The linear relationship can be positive which is indicated by the positive Pearson correlation coefficient value or it can be negative which is indicated by the negative Pearson correlation coefficient value.

The correlation coefficient is used to measure the strength and direction of the linear relationship of two variables and there is not always a causal relationship between the two variables. The correlation only explains the strength of the relationship without considering the causality relationship, which one is affected and which one is influencing. The formula for calculating the Pearson linear correlation coefficient is as follows [9]:

$$
r_{x y}=\frac{\sum(X-\bar{X})(Y-Y)}{\sqrt{\sum(X-\bar{X})^{2}} \sqrt{\sum(Y-\bar{Y})^{2}}}
$$

information:

$r$ : correlation

$X:$ in-situ sea surface temperature

$\bar{X}:$ in-situ sea surface temperature average

$Y:$ ex-situ sea surface temperature

$\bar{Y}:$ ex-situ sea surface temperature average

This study verified the data using the Pearson correlation coefficient calculation which was processed with RStudio software to determine the relationship between the two with the syntax, as follows:

$$
\text { cor (data } \$ \mathrm{X} \text {, data\$Y, method = "Pearson") }
$$

In-situ data (field sea surface temperature) act as variable " $\mathrm{X}$ " and ex-situ data (sea surface temperature satellite image) act as variable "Y".

\section{RESULTS}

Sea surface temperature data obtained in the field (in-situ) correlated with sea surface temperature data from Aqua-MODIS satellite imagery (ex-situ) based on coordinate point data for Indian Scad Fish in the Makassar Strait, South Sulawesi. The stages for testing the two data have a close relationship, as follows:

\section{Data Normality Test}

Tests of normality of in-situ sea surface temperature and ex-situ sea surface temperature need to be carried out to determine whether the data is normally distributed or not. Normality test that can be done is using the Shapiro-Wilk method. This method was chosen because each variable is less than or equal to 50 samples. The results of the normality test show that the value of the significance level is smaller than 0.05 , which is 0.0004094 , meaning that the data is not normally distributed. 
Then the normality test was carried out again using the Anderson-Darling method because the first normality test had not been fulfilled. This second normality test shows that the data is normally distributed because the significance level value obtained is greater than 0.05 , which is 0.649 .
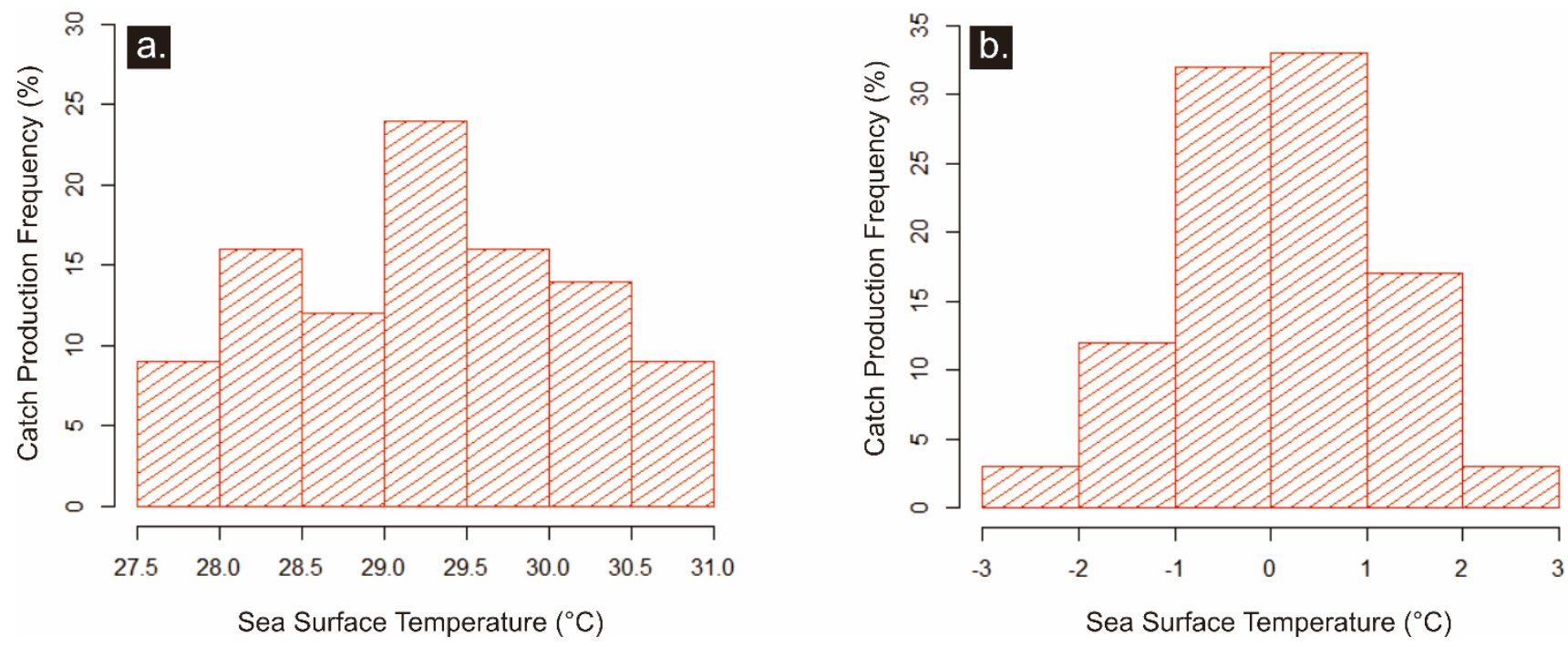

Figure 2: Normality Test of In-situ Sea Surface Temperature Data and Ex-situ Sea Surface Temperature a) Abnormal Distribution, and b) Normal Distribution

\section{Pearson Correlation Test}

After the data normality test has met the requirements, the next step is to test the correlation between in-situ sea surface temperature and ex-situ sea surface temperature using the Pearson method. Based on the Pearson correlation test shows that the value of $\operatorname{Pr}(>|t|)$ is less than 0.05 so that the in-situ sea surface temperature has a significant effect on the ex-situ sea surface temperature, every one unit increase in in-situ sea surface temperature will give an increase 0.81300 at the ex-situ sea surface temperature. The F-statistical test with a significance level of 2.2e-16 is much smaller than 0.05 , which means the regression model is very good. Meanwhile, the Pearson correlation coefficient value of 0.8065 or close to 1 means that $80.65 \%$ there is a strong linear relationship between the two variables, and $19.35 \%$ is influenced by other factors.

Tabel 1. Pearson Correlation of In-situ Sea Surface Temperature and Ex-situ Sea Surface Temperature in Makassar Strait, South Sulawesi

\begin{tabular}{lcccc}
\hline & Estimate & Std. Error & $\mathrm{t}$ value & $\operatorname{Pr}(>|\mathrm{t}|)$ \\
\hline Intercept & 6.68727 & 1.64382 & 4.068 & $0.000176^{* * *}$ \\
SST In-Situ & 0.81300 & 0.05748 & 14.144 & $<2 \mathrm{e}-16^{* * *}$ \\
\hline
\end{tabular}

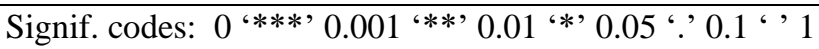

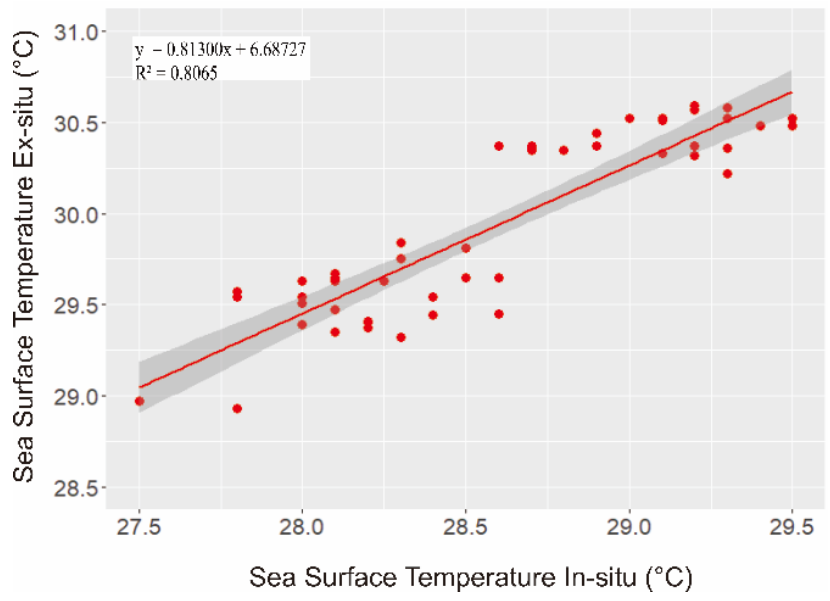

Figure 3: Correlation Graph of In-Situ Sea Surface Temperature and Ex-situ Sea Surface Temperature with Pearson Correlation Coefficient Method

This publication is licensed under Creative Commons Attribution CC BY. 
Satellite image data (ex-situ) and field data (in-situ) are due to satellite image data being limited by the presence of clouds in the atmosphere, which prevents infrared radiation from the sea surface from reaching the satellite. In the absence of clouds, solar radiation that reaches sea level during the day increases. The absence of clouds also affects the amount of net longwave radiation at sea level or the amount of longwave radiation reflected back to the ocean decreases. This may in particular affect the bias between in situ and satellite data, as well as other measures of error. The results obtained in the study [10] state that the difference between in situ sea surface temperature data and satellite imagery can be influenced by various factors, namely database, sensor or platform type, certain biases on certain platforms, and others.

\section{CONCLUSION}

Based on the results of the study, it can be concluded that there is a close relationship between in-situ sea surface temperature data and satellite imagery (ex-situ) sea surface temperature in Makassar Strait waters of $80.65 \%$. The bias of the data obtained by $19.35 \%$ could have been influenced by the presence of clouds in the atmosphere and solar radiation.

\section{ACKNOWLEDGMENT}

Thank you to the NASA Ocean Color web (http://oceancolor.gsfc.nasa.gov) for providing the sea surface temperature and sea surface chlorophyll-a data set. This research was also supported by purse seine fishermen in Siddo Village, Barru Regency and Sanane Island, Pangkajene Kepulauan Regency, South Sulawesi.

\section{REFERENCES}

[1] Sukoraharjo, S. Suryo., D. Manurung., I. Jaya., B. P. Pasaribu dan Jonson. 2011. Menduga Penaikan Massa Air dengan Menganalisis Pola Pergerakan Angin di Perairan Selat Makassar. Jurnal Kelautan Perikanan, 6(3):149-160.

[2] Nontji, A. 2007. Laut Nusantara. Djambatan. Jakarta.

[3] Jufri, Adi., M. A. Amran., M. Zainuddin. 2014. Karakteristik Daerah Penangkapan Ikan Cakalang pada Musim Barat di Perairan Teluk Bone. Jurnal IPTEKS PSP. Vol.1, No.1: 1-10.

[4] Safruddin. 2013. Distribusi Ikan Layang (Decapteru,s spp) Hubungannya dengan Kondisi Oseanografi di Perairan Kabupaten Pangkep, Sulawesi Selatan. Torani: Jurnal Ilmu Kelautan dan Perikanan, ISSN:0853-4489, 23(3):150-156.

[5] Putra, E., J. L. Gaol, V. P. Siregar. 2012. Relationship chlorophyll-a concentration and sea surface temperature with primary pelagic fish cathes in java sea from modis satellite images. Jurnal Teknologi Perikanan dan Kelautan. Vol. 3. No. 2 November 2012: 1-10. ISSN 2087-4871

[6] Mistiyani, N. D. Simbolon, D. S. Zulkarnain. 2018. Pemetaan Daerah Penangkapan Ikan Layang Berbasis Suhu Permukaan Laut dan Hasil Tangkapan. UT Fishing Management and Technology [1139]

[7] Shapiro, S.S., M. B. Wilk \& Mrs. H. J. Chen (1968) A Comparative Study of Various Tests for Normality, Journal of the American Statistical Association, 63:324, 1343-1372, DOI: 10.1080/01621459.1968.10480932

[8] Stephens, M. A. 1974. EDF Statistics for Goodness of Fit and Some Comparisons. Journal of the American Statistical Association. 69: $730-737$.

[9] Walpole, R. E. 1993. Pengantar Statistika Edisi Ke-3. Jakarta: PT Gramedia Pustaka Utama.

[10] Alvera-Azcarate, A., C. Troupin, A. Barth, J. Beckers. 2011. Comparison between satellite and in situ sea surfece temperature data in the Western Mediterranean Sea. Ocean Dynamics.

\section{AuTHORS}

First Author - Nur Abrianti Isamiah Baharuddin, Master Student, Hasanuddin University, nurabriantiislamiah0510.fishery@gmail.com

Second Author - Author name, qualifications, associated institute (if any) and email address.

Third Author - Author name, qualifications, associated institute (if any) and email address.

Correspondence Author - Nur Abrianti Isamiah Baharuddin, email address, nurabriantiislamiah0510.fishery@gmail.com, $+6285242104597$ 